\title{
Phytochemical, pharmacological and tissue culture studies of some important species of the genus Barleria L. (Acanthaceae) - a review
}

\author{
Sudheer WN \& Praveen $\mathrm{N}^{*}$ \\ Department of Life Sciences, CHRIST (Deemed to be University), Bengaluru 560 026, Karnataka, India \\ *Email: praveen.n@christuniversity.in
}

ARTICLE HISTORY

Received: 03 February 2021

Accepted: 18 May 2021

Available online: 01 July 2021

\section{KEYWORDS}

Acanthaceae

Metabolites

Flavonoids

Barlerin

Iridoid glycosides
ABSTRACT

Ayurvedic sciences helped the early humans to overcome chronic dangerous diseases. There are thousands of varieties of herbs and medicinal plants used to overcome such dreadful diseases. The genus Barleria L. belongs to family Acanthaceae, a medicinally significant group of plants having diversified phytochemicals used for different pharmacological properties. It has been utilized since ancient times for medicinal purposes. It has many plant secondary metabolites such as terpenes, flavonoids, lignins, alkaloids, particularly the iridoid glycosides. The secondary metabolites extracted from Barleria spp. show potential pharmacological activities viz., anti-microbial, anti-inflammatory, anti-oxidant, anti-fertility, anti-arthritic and anti-ulcer activity. In view of these, present review is focused on the phytochemistry, pharmacology and tissue culture studies of some of the important species of the genus Barleria $\mathrm{L}$.

\section{Introduction}

Since ancient time, mankind has depended on plants for his food, shelter, clothing and medicines. The science of Ayurveda allows us to become familiar with plants and their medicinal properties. The genus Barleria L. belongs to the family Acanthaceae and there are many reports proving the medicinal properties of this genus. A total of 300 species have been reported globally, mainly distributed throughout the Asia, South Africa and most of the tropical countries (1). Numerous phytochemicals reported from various species of Barleria which are responsible for medicinal properties (2). The Barleria species are usually seen as herbs or shrubs with simple leaves which are usually arranged in decussate manner and few species have sharp apex. They have diverse coloured tubular flowers with epipetalous stamens, arranged in solitary, axillary and cymes. Thorns/spines are present at the axial positions, which are modified bracts (3). In ayurvedic medicine, Barleria species are used for their anti-fertility, antidiabetic, cytoprotective, immunoprotective properties (4). Especially, Iridoid glycosides which are present in Barleria play a major role in building up the pharmacological profile. In this review, we have discussed about the phytochemicals, pharmacological activities and plant tissue culture studies of some important species of genus Barleria.

\section{Phytochemistry of Barleria species}

Macroscopic and microscopic studies on Barleria helps us to understand the chemical compositions present in the plant body right from leaves, stem and roots. There are many pharmacologically active compounds present in the plant body of $B$. prionitis. The decoctions of the $B$. prionitis leaves reveal the presence of metabolites like alkaloids, tannins and oils. Tannins are also present in the bark of $B$. prionitis (5). Glycosides like scutellarein 7-rhamnosylglucoside, is reported in $B$. prionitis (6). Acetyl Barlerin A with molecular formula $\mathrm{C}_{21} \mathrm{H}_{28} \mathrm{O}_{13}$ and Barlerin B with molecular formula $\mathrm{C}_{19} \mathrm{H}_{26} \mathrm{O}_{12}$ are isolated and compared with the standard spectroscopic data and they are found to be iridoids isolated from $B$. prionitis (7). Later, Barlerin is also reported to be present in the methanolic extract of $B$. dinteri (8). From the ethanolic extracts of $B$. prionitis, a compound known as Balarenone was isolated. Spectral studies helped to find the molecular formula as $\mathrm{C}_{29} \mathrm{H}_{34} \mathrm{O}_{5}$ (9). The gum fraction extracted from the ethanolic extract of the $B$. prionitis showed the presence of Barlerinoside, which is a phenylethanoid glycoside. Spectral data revealed that the molecular formula of the compound is $\mathrm{C}_{41} \mathrm{H}_{56} \mathrm{O}_{24}$ with chemical name $\beta(3,4$-dihydroxyphenyl)ethyl-a-L-rhamnopyranosyl-(1'"' $\left.\rightarrow 3^{\prime \prime \prime}\right)-\alpha-L-$

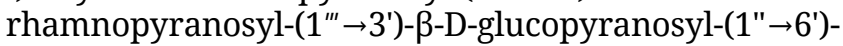
4-O-(3,4-dihydroxycinnamoyl)- $\beta$-D-glucopyranoside (10).

C Sudheer \& Praveen (2021). This is an open-access article distributed under the terms of the Creative Commons Attribution License, which permits unrestricted use, distribution and reproduction in any medium, provided the original author and source are credited (https://creativecommons.org/licenses/by/4.0/). 
In $B$. lupulina the aerial parts are subjected to metabolite analysis using ethanol and hexane. During chromatography technique, $\mathrm{CH}_{2} \mathrm{Cl}_{2}$-methanol at ratio of $(80: 20)$ fractions showed presence of shanzhiside methyl ester along with Barlerin (8-0acetylshanzhiside methyl ester) and Acetyl Barlerin (6,8-0,0-diacetylshanzhiside methyl ester) which are chief iridoid glucosides present in Barleria spp. (11). In aerial parts of $B$. lupulina, minor iridoid compounds like ipolamiidoside and 6-Oacetylshanzhiside methyl ester are isolated and they are characterised using spectroscopic analysis (12). Compounds like 6-0-p-methoxy-cis-cinnamoyl-8-0acetylshanzhiside methyl ester,6-0-p-methoxy-transcinnamoyl-8-O-acetylshanzhiside methyl ester, 6-0-pcis-coumaroyl-8-0-acetylshanzhiside methyl ester and 6-O-p-trans-coumaroyl-8-O-acetylshanzhiside methyl ester are isolated from leaves of $B$. lupulina (13). In the flowers of $B$. lupulina lupilinoside is isolated which is an iridoid diglucoside. Chemically it is 8-O- acetyl-2'-O-( $\beta$-gluco-pyranosyl) mussaenoside with molecular formula $\mathrm{C}_{25} \mathrm{H}_{38} \mathrm{O}_{16}$ (14). In the ethanolic extract of $B$. lupulina, iridoid glycosides like 8-O- acetylipolamiidic acid, 8-0-acetyl-6-O-(pmethoxy-cis-cinnamoyl)shanzhiside and 8-0-acetyl-6O-(p-methoxy-trans- cinnamoyl)shanzhiside were isolated and iridoid rich component having other active compound showed potent alkaline phosphatase activity (15). Spectral analysis conducted on the aerial extracts from $B$. lupulina showed the presence of chakyunglupulins $A$ and $B$, which are the 4,8,8-trimethylcyclooct- 2-enone derivatives. The molecular formula of chakyuglupulin $\mathrm{A}$ and $\mathrm{B}$ was found to be $\mathrm{C}_{11} \mathrm{H}_{18} \mathrm{O}_{4}$ (16). In the aqueous extract of $B$. lupulina, 4-ethylcatechol, 4-vinylcatechol and 4methylcatechol were isolated (17). The ethanolic extracts from $B$. lupulina showed the presence of Barlupulins, which are iridoid glycosides. NMR spectroscopic observations reveal that Barlupulin A has molecular formula $\mathrm{C}_{20} \mathrm{H}_{28} \mathrm{O}_{13}$, Barlupulin $\mathrm{B}$ has molecular formula with $\mathrm{C}_{22} \mathrm{H}_{30} \mathrm{O}_{14}$, and Barlupulin $\mathrm{C}$, D has the same molecular formula $\mathrm{C}_{17} \mathrm{H}_{24} \mathrm{O}_{12}$ (18). Another iridoid glycoside namely Barlupulin $\mathrm{C}$ methyl ester was isolated from aerial parts of $B$. lupulina. NMR data suggests that the molecular formula of the compound is $\mathrm{C}_{18} \mathrm{H}_{26} \mathrm{O}_{12}$ (19). Compounds like cyclobutane,1,1- dimethyl-2-octyl, 1Hentetracontanol, 1,2-Benzenedicarboxylic acid, diisooctyl ester, 1-Hentetracontanol, 2-Hexyl-1-octanol were isolated from the essential oils of $B$. lupulina (20).

In Barleria buxifolia Linn., roots were subjected to benzene extraction and it is seen that pigments like Barleriaquinone. The molecular weight and chemical formula of Barleriaquinone is found to be 238.0659 and $\mathrm{C}_{15} \mathrm{H}_{10} \mathrm{O}_{3}$. Spectroscopic studies help us to understand that the chemical name of the isolated quinone is 1-hydroxy-7-methylanthroquinone (21). Spectroscopic analysis helps us to find out that different compounds are present in $B$. strigosa. Striogoside is a compound isolated having a chemical name 4-hydroxyphenylethyl 4-O- $\beta$-D-glucopyranosyl$(1 \rightarrow 3)-O-\alpha-L-r h a m n o p y r a n o s i d e$ with molecular formula $\mathrm{C}_{20} \mathrm{H}_{30} \mathrm{O}_{11}$ and another iridoid compound with chemical name 10-O-trans-coumaroyl-eranthemoside with molecular formula $\mathrm{C}_{24} \mathrm{H}_{28} \mathrm{O}_{11}$ (22). From the methanolic extracts of $B$. strigosa parvifloroside A and $B$ were isolated, which are phenylethanoid glycosides. The molecular formula of parvifloroside $\mathrm{A}$ and $\mathrm{B}$ is found to be $\mathrm{C}_{29} \mathrm{H}_{36} \mathrm{O}_{15}$, these compounds show great anti-oxidant properties (23).

From the ethanolic extracts of Barleria trispinosa an iridoid compound is isolated with molecular formula $\mathrm{C}_{25} \mathrm{H}_{38} \mathrm{O}_{16}$ having chemical name 6- $\alpha$-Lrhamnopyranosyl-8-O-acetylshanzihiside methyl ester, which is illustrated using NMR spectroscopy (24). In Barleria acanthoides there are diversified compounds isolated from the n-butanol extracts. Spectral analysis suggests the presence of compounds called Barleriside A and B. Molecular formula of the isolated compounds are $\mathrm{C}_{21} \mathrm{H}_{20} \mathrm{O}_{10}$ and $\mathrm{C}_{29} \mathrm{H}_{35} \mathrm{O}_{15}$. Chemical name of the Barleriside $\mathrm{A}$ is found to be 8,4 '-dihydroxy-6-O-( $\beta$-D-glucopyranosyl)flavone and Barleriside $B$ is 1-O-caffeoyl-6-(3',4'dihydroxyphenyl)ethyl-O-a-L-rhamnopyranosyl-

$(1 \rightarrow 3) \beta$-d-glucopyranoside (25). In the n-butanolic subfraction of methanolic extract from $B$. acanthoides showed presence of neolignan diglycoside called Barlericin. High resolution fast-atom bombardment mass spectroscopic results suggested that the molecular formula of the isolated Barlericin is $\mathrm{C}_{31} \mathrm{H}_{40} \mathrm{O}_{15}$ (26). Mixture of 4-hydroxy-trans-cinnamic acid alkyl esters and oleanolic acid (triterpene compound) were isolated from the methanolic extract of Barleria cristata (27). The list of important phytochemicals present is represented in Table 1.

\section{Analytical methods for standardization of phytochemicals in Barleria species}

Development of validated analytical methods is very important to analyse the phytochemicals in the polyherbal extracts. Chromatographic techniques were employed to screen the biochemicals in the plant extracts of Barleria. Important metabolites like Barlerin, Acetylbarlerin and Shanzhisidemethylester from Barleria spp. were analysed using HPTLC. It is seen that mobile phase having chloroformethylacetate- methanol-acetic acid at concentration of 3:3:3:1 showed best results at $233 \mathrm{~nm}$. Upon statistical data analysis it was seen that highest content of barlerin was found in the shoot regions of $B$. prionitis. Acetylbarlerin is found highest in the leaves of $B$. lupilina and Shanzhisidemethylester content is found highest in leaves of $B$. prionitis (31). HPTLC and RP-HPLC methods were developed for B. cristata. An optimised HPTLC technique was developed with the help of solvent system having methanol: ethyl acetate: toluene: formic acid at (1: 1: 7.5: 0.2) to separate and quantify the significant anti-oxidants like quercetin, apigenin and naringenin at $308 \mathrm{~nm}$. In RP-HPLC method, potassium dihydrogen phosphate along with methanol at 30:70 was used as solvent system and the detection of biochemicals was done at $330 \mathrm{~nm}$. These standardised analytical methods helped in evaluating the phytochemical markers in plasma (32). Various saponins were identified in the leaf extracts of $B$. cristata. It is seen that in the optimised mobile phase having chloroform: glacial acetic acid: methanol: water at 6.4:3.2:1.2:0.8 ratio was used for analysis. Anisaldehyde-sulphuric acid reagent is used to obtain the chromatogram and later saponins were analysed from plates at $500 \mathrm{~nm}$ (33). 
In $B$. prionitis, HPTLC technique was developed to quantify the various biochemicals. Saponins were analysed with optimized solvent system having chloroform: glacial acetic acid: methanol: water at ratio of 6.4:3.2:1.2:0.8. Chromatograms were compared with gallic acid, and it is seen that extracts showed presence of tannins. Flavonoids were qualitatively estimated using ethyl acetate: formic acid: glacial acetic acid: water at 10:1.1:1.1:2.6 ratio as solvent system. It is seen that leaf showed the highest percentage in the presence of saponins, tannins and related metabolites when compared to roots (34). GCMS analysis was employed to analyse the biomolecules present in different extracts of $B$. buxifolia L. and B. montana. A total of 26 compounds were analysed which comes under broader class of flavonoids, alkaloids, terpenoids and tannins from ethanolic extract of $B$. montana. It is seen that injector at $280{ }^{\circ} \mathrm{C}$ and helium gas with the flow at 0.8 $\mathrm{ml} / \mathrm{min}$ is used in improved protocol (35). Similarly in $B$. buxifolia, 30 compounds were analysed from methanolic extract of leaf. It is seen that injector at 230 to $250{ }^{\circ} \mathrm{C}$ and helium gas with the flow at $1 \mathrm{ml} / \mathrm{min}$ was used in improved protocol (36).

\section{Pharmacology of Barleria species}

\section{Anti-viral property}

Cytopathic effect assay is conducted against respiratory syncytial virus (A2 strain) using 6-O-cis-pcoumaroyl-8-O-acetylshanzhiside methyl ester and 6O-trans-p-coumaroyl-8-O-acetylshanzhiside methyl ester and it is found that 1:3 ratio of the cis and trans isoforms of above mentioned compounds isolated from $B$. prionitis showed best half maximal inhibitory concentration $\left(\mathrm{IC}_{50}\right)$ and half best maximal effective concentrations $\left(\mathrm{EC}_{50}\right)$ at $42.2 \mu \mathrm{g} / \mathrm{ml}$ and $2.46 \mu \mathrm{g} / \mathrm{ml}$ respectively (37). Plaque inhibition assay suggest that the anti-viral activity of $B$. lupulina extracts against Herpes simplex virus type 2 strain G, and some medical isolates of HSV-2 is very much promising and its activity is compared with Clinacanthus nutans which is also an Acanthaceae member. It is seen that C. nutans anti-viral activity is not up to the mark when compared to $B$. lupulina. Yield reduction assay also suggests that $B$. lupulina has promising viricidal effects (38).

\section{Anti-fertility activity}

Methanolic root extracts of $B$. prionitis reduced the fertility in male rats. It is seen that administration of $100 \mathrm{mg} / \mathrm{l}$ concentration of the plant extracts obstructed the spermatogenesis in rats. Anatomical studies helped to understand that the spermatids, cross sectional area of sertoli cells and leydig cells drastically reduced. Fertility tests conducted on male rats proved the anti-fertility effect of $B$. prionitis (39, 40). In northern Thailand folk medicine, Barleria species are used in anti-fertility and when a study conducted on wistar male rats proved that $B$. strigosa played significant role in inducing hormonal imbalance and ultimately reducing the sperm count and making rats infertile (41). Different fractions of crude methanol extract from $B$. prionitis root were eluted with $3: 1$ and 1:1 concentrations of trichloromethane with methanol. The fertility ability of the treated individuals decreased rapidly and the parameters like sperm motility, spermatogenic cells count and biochemical parameters like total protein, sialic acid and glycogen content were drastically changed in treated rats. Fraction eluted with 1:1 ratio of trichloromethane with methanol showed best results (42).

\section{Anti-inflammatory activity}

$B$. lupulina is used as anti-inflammatory agent and its extracts are used as antidote for snake poision (43). Methanolic extracts of leaves and shoots of $B$. lupulina showed best anti-inflammatory activity against carrageenan and serotonin induced paw oedema and the extract showed results which are equal to that of indomethacin, which is a standard drug at $300 \mathrm{mg} / \mathrm{kg}$ concentration which is ideal (44). Another study was carried out on different animal models having carrageenan induced paw oedema and ethyl phenylpropiolate induced ear oedema. Myeloperoxidase activity (for neutrophil migration), trypan blue exclusion and MTT cytotoxicity assays demonstrates that methanolic extracts from $B$. lupulina showed best anti-inflammatory activities (45). Alkyl catechols, which are present in hot aqueous extracts of $B$. lupulina are found to be playing an important role in activating Nrf2 defence pathway which ultimately helps the organism in overcoming the inflammation (17). The pharmacologically active components having iridoid glucosides in the aqueous fraction (TAF) of $B$. prionitis showed best results with respect to antiinflammation. The study was carried on different sets of rats which have induced the inflammation using carrageenan, histamine and dextran. Treatment of these effected rats with TAF fraction showed comparable results with respect to standard drugs like Ibuprofen. Leucocyte migration inhibition assay also suggested that TAF fraction of $B$. prionitis taken from methanol extract showed best results (46). Membrane stabilization activity and mast cell protection activity is studied after the administration of hydro alcoholic extracts of $B$. prionitis in rats. It is seen that ethanolic extract at $10 \mu \mathrm{g} / \mathrm{ml}$ concentration showed best results with respect to membrane stabilization and it is comparable to that of indomethacin, standard drug at $10 \mu \mathrm{g} / \mathrm{ml}$ concentration. The percentage of degranulation of mast cells is monitored and it is seen that $10 \mu \mathrm{g} / \mathrm{ml}$ concentration showed best results against the toxicant compound 48/80 (47). Carrageenan induced paw oedema model is established and effect of the anti-inflammatory activity of methanolic extract from $B$. prionitis is estimated. It is seen that methanolic extract at $500 \mathrm{mg} / \mathrm{kg}$ concentration showed best efficiency in reducing the inflammation (48). 8-O-acetyl shanzhiside methyl ester, shanzhiside methyl ester rich component from $B$. prionitis showed inhibition against myeloperoxidase, matrix metalloproteinase-9 and elastase enzymes and release of cytokines which prove the antiinflammatory activity (49).

The effect of $B$. cristata leaf extracts on carrageenan induced paw oedema, acetic acid induced vascular permeability and castor oil induced diarrhoea was studied and it was seen that $500 \mathrm{mg} / \mathrm{kg}$ concentration of the extract showed best results in 
inhibiting the oedema, inhibited the vascular permeability. Indomethacin is used as a standard drug at $10 \mathrm{mg} / \mathrm{kg}$ in all studies (50). Leaves of $B$. cuspidate are studied for their wound healing property. The methanolic fractions at $10 \% \mathrm{w} / \mathrm{w}$ and $15 \% \mathrm{w} / \mathrm{w}$ concentrations were used for the study. It was seen that these fractions showed best results with respect to wound healing (i.e., decrease in the wound length) and comparable to that of the nitrofurazone which is the standard drug (51). Formalin at the concentration of $0.1 \mathrm{mg} / \mathrm{kg}$ is administered to the albino Wistar rats to induce the inflammation. It is seen that leaf ethanol extracts from B. montana at $300 \mathrm{mg} / \mathrm{kg}$ body weight concentration reduced the inflammation. The blood biochemistry parameters like levels of haemoglobin, red and white blood cells were also taken into consideration and the efficiency is compared with indomethacin at $25 \mathrm{mg} / \mathrm{kg}$ body weight concentration (52).

\section{Neuroprotectivity activity}

Methanolic extracts of $B$. lupulina are studied for their neuro-pharmacological activity in mice, which are induced by propylene glycol. General behaviour tests for sound response, touch and pain responses are conducted on different sets of mice and rats. Along with these muscle relaxant tests like traction test, rotarod performance tests, $30^{\circ}$ inclined tests are conducted. It is seen that in all the above tests conducted, on overall $B$. lupulina extracts show promising pharmacological activity when compared to standard neuroleptics (53).

\section{Anti-oxidant activity}

DPPH radial scavenging activity suggest that the availability of the anti-oxidant molecules are present in the methanolic extracts of whole $B$. prionitis and from the leaf extracts of $B$. greenii, as they showed ideal half maximal effective concentration. The efficiency is compared with that of ascorbic acid which is a strong anti-oxidant (54). The antioxidant property of the ethanolic extracts from $B$. prionitis helped in reversing the cataract which is induced with the help of galactose and selenite at 25 moles $/ \mathrm{kg}$ body weight concentration. Ethanolic extract at 200 $\mathrm{mg} / \mathrm{kg}$ and $400 \mathrm{mg} / \mathrm{kg}$ body weight concentration showed best results in reducing the oxidative stress (55). Ferric thiocyanate method and thiobarbyturic acid methods also suggest that the ethanolic extract from $B$. prionitis have promising anti-oxidant activity (56). Ferrous reducing power, DPPH radial scavenging activity, nitric oxide radical scavenging activity, hydrogen peroxide radical scavenging activity, superoxide anion scavenging activity and $\mathrm{ABTS}^{+}$radical cation decolourisation assay were conducted on leaf and root extracts of $B$. noctiflora and root extracts showed best results and performed best anti-oxidant activity (57). The ethanolic extracts from $B$. cristata were checked for their anti-oxidant activity. DPPH assay, $\mathrm{ABTS}^{+}$assay and FRAP assay were conducted to check the efficiency of the ethanolic extracts. It is seen that ethanolic extracts showed best results in all conducted assays and it is compared with that of butylated hydroxyl toluene (BHT) which is a standard anti-oxidant (58). DPPH radical scavenging assay, nitric oxide radical scavenging assay was conducted on ethanolic extracts of $B$. gibsonii. The results suggest that the presence of pharmacologically significant antioxidant molecules which showed their efficiency in scavenging the DPPH radicals which was compared with standard anti-oxidant molecule, ascorbic acid. And scavenging of nitric oxide radicals from sodium nitroprusside were also seen which ultimately proved their promising anti-oxidant activity (59).

\section{Immuno-protective activity}

Immuno-protectivity of the methanolic extracts from $B$. lupulina was proved with the help of checking the parameters like WBC count, spleen WBC count, spleen weight and delayed type hypersensitivity reaction on footpad thickness. It is seen that $600 \mathrm{mg} /$ $\mathrm{kg}$ concentration of the extract showed good results along with $300 \mathrm{mg} / \mathrm{kg}$ (60). Oral administration of the iridoid fraction of the methanolic extract from $B$. prionitis triggered the immune response in the rats. Different tests like neutrophil adhesion test, haemagluttinating antibody titre test, delayed type hypersensitivity response test, cyclophosphamideinduced immunosuppression test and macrophage phagocytosis by carbon clearance test were conducted to check the efficiency of the extracts. It is proved that shanzhiside methyl ester and barlerin rich iridoid component helps in immunomodulation (61).

\section{Anti-cancer activity}

The cytotoxicity effect of the Barleria quinones (Barleriaquinone-I, Barleriaquinone-II) isolated from $B$. buxifolia roots are studied and it is seen that Barleriaquinone-II showed best $\mathrm{LD}_{50}$ when compared to Barleriaquinone-I in human breast adenocarcinoma cells (MCF7) (62). The anti-cancer activity of the methanolic extracts from $B$. grandifolia were studied against cancer cell lines i.e., A- 549 (human lung cancer) cells, Dalton's lymphoma ascites. Methanolic extracts showed best halfmaximal inhibitory concentration against dalton's lymphoma ascites with the value $137.2 \mu \mathrm{g} / \mathrm{ml}$. Various parameters like tumor weight, viable cell count, tumor volume were taken into consideration and the methanolic extracts showed best anti-tumour activity (63).

\section{Anti-arthritic activity}

$B$. lupulina from the ancient days is used for treating arthritis. Scientifically it is proved that methanolic extracts from the leaves showed promising activity against arthritis. Study was carried out on different animal models of induced arthritis like formalininduced arthritis, collagen type II-induced arthritis, monosodium iodoacetate induced osteoarthritis. It is seen that at $300 \mathrm{mg} / \mathrm{kg}$ and $600 \mathrm{mg} / \mathrm{kg}$ concentrations of the administered extracts showed comparable promising anti-arthritic activity with that of indomethacin at $10 \mathrm{mg} / \mathrm{kg}$ concentration (60). Artificially arthritis is induced using chemicals like formaldehyde and freund's adjuvant (FCA) in the sprague-dawley rats. It is seen that ethanolic extracts of $B$. prionitis leaves showed decreased arthritis score and paw volume which was increased as a sign of 
arthritis. Ethanolic extract of concentration $250 \mathrm{mg} /$ $\mathrm{kg}$ showed best results with respect to all tests conducted. The efficiency of anti-arthritic activity is checked with the standard drug, diclofenac at $4 \mathrm{mg} /$ $\mathrm{kg}$ body weight concentration (64).

\section{Anti-Ulcer activity}

Aerial parts (Leaves, shoot regions) of $B$. lupulina were subjected to methanolic extraction and their anti-ulcer properties are studied. It is seen that in pylorus ligated rats the methanolic extract of $B$. lupulina at $200 \mathrm{mg} / \mathrm{kg}$ concentration showed promising anti-ulcer activity and the results are comparable with famotidine at $30 \mathrm{mg} / \mathrm{kg}$ which is the standard anti-ulcer drug. The effect of $B$. lupulina extracts on different animal models where ulcer is induced using stress, alcohol and Indomethacin. It is seen that methanolic extracts of $B$. lupulina showed best results in alcohol induced stress even when compared with famotidine and omeprazole (65). Aspirin at $200 \mathrm{mg} / \mathrm{kg}$ concentration, ethanol at 1 $\mathrm{ml} / 200 \mathrm{mg}$ concentration with respect to body weight is administered to induce ulcer in rats. Iridoid fraction from $B$. prionitis at $200 \mathrm{mg} / \mathrm{kg}$ body weight concentration showed best efficiency in reducing the ulcers. Cold-restraint stress and pylorus ligated induced ulcer models were also developed and the activity of the iridoid fraction on them is checked. Many parameters like acid output, $\mathrm{pH}$ value and gastric juice amount were taken into consideration. It is concluded that $B$. prionitis extracts which are rich in iridoid fraction have promising anti-ulcer activity (66). In pylorus ligated induced ulcer, the efficiency of ethanolic extracts from $B$. gibsoni was checked for its anti-ulcer property. It is seen that acidity levels and ulcer lesions got reduced upon the administration of $500 \mathrm{mg} / \mathrm{ml}$ concentration of the extracts and its capacity to reduce ulcer lesions is compared with omeprazole at $20 \mathrm{mg} / \mathrm{ml}$ concentration.

\section{Anti-diabetic activity}

In the streptozotocin induced diabetic rats the antidiabetic activity of the methanolic extracts of $B$. lupulina is studied and it was found that at $300 \mathrm{mg} / \mathrm{kg}$ body weight concentration showed decreased amount of glucose content in the blood and showed comparing efficiency with Glibenclamide at $10 \mathrm{mg} / \mathrm{kg}$ body weight concentration (67). In another study, animals were induced with alloxan monohydrate at $150 \mathrm{mg} / \mathrm{kg}$ concentration and ethanolic extracts of $B$. prionitis were administered. It is seen that ethanolic leaf extracts showed potent anti-diabetic activity and showed the reduced glucose levels by increasing the serum insulin levels when compared to root extracts (68). Ethyl acetate fraction from the ethanolic extract of $B$. noctiflora showed promising in-vitro and in-vivo anti-diabetic activity. The anti-diabetic property was compared with glibenclamide at $10 \mathrm{mg} / \mathrm{kg}$. The ethyl acetate fraction showed reduced glucose levels in the blood which was isolated from high fat diet fed and streptozotocin induced diabetic rats at $40 \mathrm{mg} / \mathrm{kg}$ body weight concentration (69). The ability of inhibiting the a-amylase and a-glucosidase enzymes by ethanolic and petroleum ether extracts of $B$. cristata leaves proved its anti-diabetic activity. It is seen that
$100 \mu \mathrm{l}$ concentration of both extracts showed promising efficiency (70).

\section{Hepatoprotectivity}

In $B$. prionitis its iridoid rich fraction was used to study the hepatoprotectivity. The study is carried out on different rat models which are liver toxicated with drugs like carbon tetrachloride $(100 \mu \mathrm{l} / \mathrm{kg})$, galactosamine $(300 \mathrm{mg} / \mathrm{kg})$ and paracetamol $(200 \mathrm{mg} /$ $\mathrm{kg}$ ). The median lethal dose of the drug in oral administration and intraperitoneal administration is studied. Serum parameters (alkaline phosphatase, alanine transaminase, aspartate transaminease) and hepatic parameters (lipid peroxidation) are taken into consideration for the study and this rich fraction of $B$. prionitis is proved to have hepatoprotectivity (71). The methanolic extracts of $B$. montana leaves were administered in the liver damaged rats and the serum enzyme parameters were analysed. It is seen that methanolic extracts at $500 \mathrm{mg} / \mathrm{kg}$ concentration successfully inhibited the enzyme levels of serum glutamic oxaloacetic transaminase (SGOT) and serum glutamic pyruvic transaminase (SGPT) and the efficiency is compared with silymarin which is standard drug against liver disorders. Anatomical studies at tissue level also suggested that $B$. montana has capacity to repair the damaged liver tissues (72). Another study was carried out on liver damaged animal model which is caused with the help of carbon tetrachloride. It is seen that methanolic extracts from the aerial parts of $B$. montana at the concentration of $400 \mathrm{mg} / \mathrm{kg}$ and $800 \mathrm{mg} / \mathrm{kg}$ reduced the serum sensitive enzymes levels for the liver damage i.e., serum glutamic oxaloacetic transaminase, serum glutamic pyruvic transaminase, alkaline phosphatase (73).

\section{Anti-bacterial property}

Compounds like Balarenone, pataline, 13,14-secostigmasta-5,14-diene-3-a-ol which were isolated from the crude extract of $B$. prionitis showed anti-bacterial property especially against Bacillus cereus (ATCC 14579) and Pseudomonas aeruginosa (ATCC 27853) (9). Different types of plant extracts using soxhlet apparatus were developed from the dried leaves of $B$. prionitis; among them ethanolic extract at $10 \mathrm{mg} / \mathrm{ml}$ showed best anti-bacterial activity against Staphylococcus aureus followed by Salmonella typhi, Vibrio cholera, Escherichia coli (74). Different fractional extracts made out of hexane and ethyl acetate from $B$. prionitis showed anti-bacterial activity (75). Different solvent extracts like methanol, ethanol, chloroform, di-chloromethane, acetone and water of B. montana Nees are studied for their antibacterial property. Anti-bacterial study is carried out on species like Bacillus subtilis, Streptococcus pneumoniae, Staphylococcus aureus, Escherichia coli, Salmonella typhi, Pseudomonas aeruginosa, Klebsiella pneumoniae and Proteus vulgaris. It is seen that acetone extracts showed best anti-bacterial property in the decreasing order against Pseudomonas aeruginosa, Escherichia coli and Salmonella typhi. The efficiency is compared with the standard drug streptomycin (76). The efficiency of the methanolic extracts of $B$. montana at $100 \mathrm{mg} / \mathrm{ml}$ and $200 \mathrm{mg} / \mathrm{ml}$ concentration were tried on different species of 
gram-positive bacteria like Bacillus subtilis, B. cereus, $B$. pumilis, Staphylococcus aureus and gram-negative bacteria like Escherichia coli, Psuedomonas aeuriginosa, P. vulgaris, Serratia marceseans. It is seen that the efficiency was moderate and that is compared with $10 \mu \mathrm{g} / \mathrm{ml}$ chloramphenicol, which is the standard drug (73). The essential oil extracted from $B$. lupulina having many important phytochemicals like cyclobutane,1,1-dimethyl-2-octyl, 1-Hentetracontanol, 1,2-Benzenedicarboxylic acid, diisooctyl ester, 2-Hexyl-1-octanol showed its antibacterial affect against the species like Bacillus pumilus and Staphylococcus aureus (20).

\section{Anti-fungal activity}

Minimum inhibitory concentration and minimum fungicidal concentrations of the extracts of petroleum ether, dichloromethane from $B$. albostellata showed best results against Candida albicans (ATCC 10231). In the same way the ethanolic extracts of $B$. greenii leaves showed highest minimum inhibitory dilution and proved its fungicidal activity and that efficiency is similar to that of its root and stem which ultimately helps the harvesters to go with plant part substitution to replace the less available parts (54). Methanolic extract of $B$. montana at concentration of $100 \mathrm{mg} / \mathrm{ml}$ and $200 \mathrm{mg} / \mathrm{ml}$ showed moderate anti-fungal activity against fungal species like Aspergillus niger, Rhizopus stolonifer, Sacharomyces cerevisiae and Pencillium chrysogenum. The efficiency is compared with that of $10 \mu \mathrm{g} / \mathrm{ml}$ nystatin (73). Hot water extracts from the aerial parts of $B$. grandiflora showed promising antifungal activity against $A$. fumigatus. It is seen that the extracts down regulated the metabolic pathways which are very much important for the survival and pathogenicity of the A. fumigatus (77). Natural dye extracted from aerial parts of $B$. prionitis showed anti-fungal activity against species like $A$. flavus, $A$. niger, $A$. parasiticus, Fusarium moniliforme and Penicillium canescens. The minimum inhibitory concentration of the natural dye against the mentioned fungal species ranges like $23.25,22.75,23.5,22.5$ and $23 \mu \mathrm{g} /$ ml. The fabrics which are made out of this natural dye is recommended for textile purposes (78).

\section{Anti-diarrhoeal activity}

Iridoid glycoside component isolated from $B$. prionitis was studied for its anti-diarrhoeal activity. Different tests like PGE2-induced enteropooling, charcoal transit test was conducted and it is seen that iridoid component successfully inhibited the enteropooling and fluid transition. $100 \mathrm{mg} / \mathrm{kg}$ concentration of the extract inhibited the castor oil induced diarrhoea and the efficiency is compared with loperamide, which is a standard drug (79).

\section{Anti-hypersensitive activity}

Methanolic extract of the leaves of $B$. prionitis is employed for studying the anti-hypersensitive activity. Hypersensitivity is induced in the rat with the help of Deoxycoticosterone acetate (DOCA) salt at the concentration of $20 \mathrm{mg} / \mathrm{kg}$ body weight. It was observed that methanolic extract at $400 \mathrm{mg} / \mathrm{kg}$ showed best results in reducing hypertension (80).

\section{Marketed medicinal formulations from Barleria spp.}

Barleria species are used in formulation of herbal toothpastes. Vicco vajradanti (81) is a herbal toothpaste made from $B$. prionitis, which have capacity to reduce the salivary glucose and $\mathrm{pH}$. It is also seen as a chief ingredient in Patanjali Dantkanti (82). B. prionitis is the chief component in Sahacharadikashayam, an ayurvedic polyherbal formulation which is used as an anti-oxidant (83). Whole plant is of $B$. prionitis is used in the polyherbal formulation of Maharasnadikwath. This liquid extract showed great anti-arthritic potential with anti-oxidant activity (84).

\section{Tissue culture Studies in Barleria spp.}

Biotechnological approach helped the mankind to solve his problems in effective manner. Tissue culture is one of such biotechnological tool which helped to conserve the medicinal plant species and their medicinally important metabolites. Barleria species being threatened in the wild, there is an immense requirement for the tissue culture technique for filling the gap in the demand for the cell lines and the raw materials. The information regarding the in-vitro development of Barleria is very much limited.

It is seen that when nodal explants of $B$. prionitis cultured in the nutrient medium having $0.4 \mathrm{ppm}$ thidiazuron (TDZ) along with 1.5 ppm BAP showed best results in inducing the shoot development and the subculturing multiplication media having $5 \mathrm{ppm}$ 6-benzylaminopurine (BAP) along with 2 ppm anaphthaleneacetic acid (NAA) showed good proliferation capacity (85). Another study also revealed that nodal explants were grown on the MS media supplemented with 1.5 ppm BAP with $0.4 \mathrm{ppm}$ TDZ showed highest number of shoots and highest mean shoot length (86). Nodal explants having axillary buds were used as explants for the shoot induction and bud break in $B$. prionitis. It is seen that MS media supplemented with BAP at $8.88 \mu \mathrm{M}$ concentration showed best results. It is seen that BAP at $4.44 \mu \mathrm{M}$ concentration showed best multiplication efficiency (87). BAP at $1.5 \mathrm{ppm}$ along with NAA at 1 ppm concentration showed best response in the development of shoot from the shoot tip explant in $B$. prionitis (88). MS media supplemented with $1 \mathrm{ppm}$ BAP and $0.5 \mathrm{ppm}$ TDZ showed best results with respect to the development of shoots from the nodal explants of $B$. prionitis (89).

Development of callus is important task and it helps in the establishment of cell cultures. Callus was developed from different explants of $B$. prionitis. $0.0125 \mathrm{ppm}$ of 2,4-D along with Kinetin (KN) showed good results in development of callus from leaf explant and at $0.025 \mathrm{ppm}$ of 2,4-D along with $\mathrm{KN}$ showed good results in development of callus from shoot explants (90). MS medium supplemented with 2 ppm of IAA along with BAP showed best results with respect to the leaf explants of $B$. lupulina Lindl. and developed callus was also screened for their potential medicinal properties (91). Callus was developed from the leaf explants which were cultured on the MS medium having 2 ppm of IAA along with $1.5 \mathrm{ppm}$ of 
BAP (92). Compact green callus was developed from the leaf explants of $B$. lupulina Lindl. It is seen that MS media having $0.1 \mathrm{ppm}$ NAA along with $0.5 \mathrm{ppm}$ BAP showed best response (93).

In $B$. prionitis rooting efficiency was checked under the influence of different auxin concentrations. It is seen that Indole butyric acid at $0.4 \mathrm{ppm}$ concentration showed best root inducing capacity of the in-vitro grown shoots (86). Half strength MS media supplemented with $2.46 \mu \mathrm{m}$ Indole butyric acid (IBA) showed good response in rooting with good mean number and the length (87). $0.5 \mathrm{ppm}$ of IBA supplemented in the half strength MS media showed best results in development of roots from the in-vitro grown micro shoots of $B$. prionitis (89).

\section{Conclusion}

Biotechnological studies reveal that Barleria L. have potential drugs which help in treating chronic illness. Scientifically there are many reports which support its requirement in curing many diseases which are chronic in nature. The phytochemicals present helps to overcome different health issues like inflammation, microbial infections, diabetes, hepatic tissue related issues, cancer, arthritis, immune deficiency etc.. Most importantly the metabolites from Barleria are used in creating the organism infertile. So, consuming the crude extracts without proper dose and doctor concern may lead to cause different fertility related issues. So, with the present scientific evidence it is the responsibility of the scientific community to explore further medicinally important metabolites and use them for the benefit of the humankind.

\section{Acknowledgements}

Authors are thankful to the Head of the institution, CHRIST (Deemed to be University), Bengaluru for all the encouragement and support extended for carrying out the research work.

\section{Authors' contributions}

PN conceived the idea and edited the manuscript. SWN gathered the data and wrote the manuscript.

\section{Conflict of interests}

The authors declare that there is no conflict of interest.

\section{Supplementary files}

Table 1. Some important phytochemicals present in different species of Barleria.

Fig. 1. Molecular structure of important metabolites in the genus Barleria.

\section{References}

1. Balkwill MJ, Balkwill K. A preliminary analysis of distribution patterns in a large, pantropical genus, Barleria L.
(Acanthaceae). J Biogeogr. 1998;25(1):95-110. https://doi.org/10.1046/j.1365-2699.1998.251120.x

2. Kumari R, Kumar S, Kumar A, Goel KK, Dubey RC. Antibacterial, antioxidant and Immuno-modulatory properties in extracts of Barleria lupulina Lindl. BMC Complement Altern $\quad$ Med. 2017;17(1):1-11. https://doi.org/10.1186/s12906-017-1989-4

3. Shendage SM, Yadav SR. Revision of the genus Barleria (Acanthaceae) in India. Rheedea. 2010;20(2):81-130.

4. Khan I, Jan S, Shinwari Z, Ali M, Khan Y, Kumar T. Ethnobotany and medicinal uses of folklore medicinal plants belonging to family Acanthaceae: An updated review. MOJ Biol Med. 2017;1(2):34-38. https://doi.org/10.15406/mojbm.2017.01.00009

5. Datta PC, Biswas C. Pharmacognostic study of the leaf and bark of Barleria prionitis Linn. Pharm Biol. 1968;8(4):116169. https://doi.org/10.3109/13880206809083343

6. Harborne J. Scutellarein 7-rhamnosylglucoside from Barleria prionitis. Phytochem Rep. 1971;10(1):2822-23.

7. Taneja SC, Tiwari HP. Structures of two iridoids from Barleria prionitis Linn. Tetrahedron Lett. 1975;24:199598.https://doi.org/10.1016/S0040-4039(00)72344-6

8. Gololo SS, Bassey K, Olivier MT, Agyei NM, Shai LJ, Masoko P. Isolation of an iridoid glycoside compound from the leaves of Barleria dinteri collected from Zebediela sub-region in Limpopo province, South Africa. J Pharm Sci Res. 2017;9(8):1368-72.

9. Kosmulalage KS, Zahid S, Udenigwe CC, Akhtar S, Ata A, Samarasekera R. Glutathione S-transferase, acetylcholinesterase inhibitory and antibacterial activities of chemical constituents of Barleria prionitis. Zeitschrift fur Naturforsch. 2007;62(4):580-86. https://doi.org/10.1515/znb2007-0417

10. Ata A, Kalhari KS, Samarasekera R. Chemical constituents of Barleria prionitis and their enzyme inhibitory and free radical scavenging activities. Phytochem Lett. 2009;2(1):3740. https://doi.org/10.1016/j.phytol.2008.11.005

11. Suksamrarn A. Iridoid glucosides from Barleria lupulina. J Nat Prod. 1986;49(1):179. https://doi.org/10.1021/np50043a037

12. Byrne LT, Sasse JM, Skelton BW, Suksamrarn A, White AH. The minor iridoid glucosides of Barleria lupulina: Isolation, crystal structure and plant growth-inhibiting properties of 6 O-Acetylshanzhiside methyl ester. Aust J Chem. 1987;40(5):785-94. https://doi.org/10.1071/CH9870785

13. Tuntiwachwuttikul P, Pancharoen O, Taylor WC. Iridoid glucosides of Barleria lupulina. Phytochemistry. 1998;49(1):163-66. https://doi.org/10.1016/S00319422(97)01049-2

14. Suksamrarn S, Wongkrajang K, Kirtikara K, Suksamrarn A. Iridoid glucosides from the flowers of Barleria lupulina. Planta Med. 2003;69(9):877-79. https://doi.org/10.1055/s-200343223

15. Retno W, Yasuhiro T, Tatsurou M, Suresh A, Shigetoshi K. Alkaline Phosphatase (ALP) enhancing iridoid glucosides from the Indonesian medicinal plant Barleria lupulina. Nat Prod Commun. https://doi.org/10.1177/1934578X1000501101

16. Kim KH, Clardy J, Senger D, Cao S. Chakyunglupulins A and B two novel 4,8,8-trimethylcyclooct-2-enone derivatives from Barleria lupulina. Tetrahedron Lett. [Internet]. 2015;56(21):2732-34.

https://doi.org/10.1016/j.tetlet.2015.04.023

17. Senger DR, Hoang $M$ V, Kim KH, Li C, Cao S. Antiinflammatory activity of Barleria lupulina: Identification of active compounds that activate the Nrf2 cell defense pathway, organize cortical actin, reduce stress fibers, and improve cell junctions in microvascular endothelial cells. J Ethnopharmacol. [Internet]. 2016;193:397-407. https://doi.org/10.1016/j.jep.2016.09.017

18. Kim KH, Park YJ, Chung KH, Yip MLR, Clardy J, Senger D et al. Iridoid glycosides from Barleria lupulina. J Nat Prod. 2015;78(2):320-34. https://doi.org/10.1021/np500791a 
19. Lee SR, Clardy J, Senger DR, Cao S, Kim KH. Iridoid and phenylethanoid glycosides from the aerial part of Barleria lupulina. Brazilian J Pharmacogn [Internet]. 2016;26(3):28184. https://doi.org/10.1016/j.bjp.2016.01.002

20. Sarmad M, Mahalakshmipriya A, Senthil K. Chemical composition and in-vitro antimicrobial activity of Barleria lupulina essential oil. J Herbs Spices Med Plants. 2012;18(1):101-19.

https://doi.org/10.1080/10496475.2011.653711

21. Gopalakrishnan S, Sthanusubramania N, Raman PV. Chemical examination of roots of Barleria buxifolia Linn. structure of Barleriaquinone. Chem Pharm Bull. [Internet]. 1984;32(10):4137-39. https://doi.org/10.1248/cpb.32.4137

22. Kanchanapoom T, Noiarsa P, Ruchirawat S, Kasai R, Otsuka H. Phenylethanoid and iridoid glycosides from the Thai medicinal plant, Barleria strigosa. Chem Pharm Bull. 2004;52(5):612-14. https://doi.org/10.1248/cpb.52.612

23. Prapalert W, Santiarworn D, Liawruangrath S, Liawruangrath B, Pyne SG. Two phenylethanoid glycosides, Parvifloroside A and B, isolated from Barleria strigosa. Chiang Mai J Sci. 2017;44(1):168-75.

24. Harraz FMH, El-Halawany AM, El Gayed SH, Abdel-Sattar E. Iridoid glycosides from Barleria trispinosa. Nat Prod Res. 2009;23(10):903-38.

https://doi.org/10.1080/14786410802278350

25. Karim A, Noor AT, Malik A, Qadir MI, Choudhary MI. Barlerisides $\mathrm{A}$ and $\mathrm{B}$, new potent superoxide scavenging phenolic glycosides from Barleria acanthoides. J Enzyme Inhib Med Chem. 2009;24(6):1332-35. https://doi/org/10.3109/14756360902887046

26. Karim A, Noor AT, Malik A. Structure of barlericin, the neolignan diglycoside from Barleria acanthoides. J Asian Nat

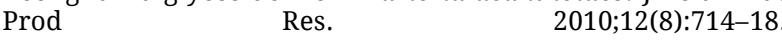
https://doi.org/10.1080/10286020.2010.489895

27. Chowdhury N, Al Hasan A, Shahidullah Tareq F, Ahsan M, Zafrul Azam ATM. 4-hydroxy-trans-cinnamate derivatives and triterpene from Barleria cristata (Acanthaceae). Dhaka Univ J Pharm Sci. 2013;12(2):173-75. https://doi.org/10.3329/dujps.v12i2.17623

28. Jiang WL, Zhang SP, Zhu HB, Hou J. Effect of 8-O-acetyl shanzhiside methylester increases angiogenesis and improves functional recovery after stroke. Basic Clin Pharmacol Toxicol. 2011;108(1):21-27. https://doi.org/10.1111/ j.1742-7843.2010.00620.x

29. Fan PC, Ma HP, Hao Y, He XR, Sun AJ, Jiang W, Li MX, Jing LL, He L, Ma J, Jia ZP. A new anti-fibrinolytic hemostatic compound 8-O-acetyl shanzhiside methylester extracted from Lamiophlomis rotata. J Ethnopharmacol. [Internet]. 2016;187:232-38. Available from: http://dx.doi.org/10.1016/j.jep.2016.04.016

30. Jiang W, Zhang S, Fu F, Zhu H, Hou J. Inhibition of nuclear factor- $\kappa B$ by 6 -O-acetyl shanzhiside methyl ester protects brain against injury in a rat model of ischemia and reperfusion. J Neuroinflammation. 2010;7:55. https://doi.org/ 10.1186/1742-2094-7-55

31. Kaur PK, Vasisht K, Karan M. HPTLC method for shanzhiside esters: Simultaneous quantitative analysis of barlerin acetylbarlerin and shanzhiside methyl ester in Barleria species. J Chromatogr Sep Tech. 2014;05(06). https://doi.org/10.4172/2157-7064.1000246

32. Rajendran J, Jacob L, Kochupappy R. Development of validated analytical methods for the simultaneous estimation of biomarkers in the leaves of Barleria cristata and bio analysis of the selected marker in plasma. J Adv Pharm Educ Res. 2014;4(4):409-16.

33. Amutha K, Doss DVA. Identification and antimicrobial activity of saponin fraction from the leaves of Barleria. 2012;3(10):4040-44. http://dx.doi.org/10.13040/IJPSR.09758232.3(10).4040-44

34. Dheer R, Swarnkar SK, Syeed F. Chromatographic analysis of Barleria prionitis Linn. Res J Pharm Technol. 2019;12(8):3679-86. https://doi.org/10.5958/0974360X.2019.00628.0

35. Sridharan S, Chinnagounder S. Evaluation of antimicrobial activity and GC-MS profiling of Barleria montana. J Pharm Res. 2012;5(5):2921-25.

36. Tamil Selvi S, Jamuna S, Thekan S, Paulsamy S. Profiling of bioactive chemical entities in Barleria buxifolia L. using GC MS analysis-a significant ethno medicinal plant. J Ayurvedic Herb Med. [Internet]. 2017;3(2):63-77.

37. Chen JL, Blanc P, Stoddart CA, Bogan M, Rozhon EJ, Parkinson N, Ye Z, Cooper R, Balick M, Nanakorn W, Kernan MR. New iridoids from the medicinal plant Barleria prionitis with potent activity against respiratory syncytial virus. J Nat Prod. 1998;61(10):1295-97. https://doi.org/10.1021/np980086y

38. Yoosook C, Panpisutchai Y, Chaichana S, Santisuk T, Reutrakul V. Evaluation of anti-HSV-2 activities of Barleria lupulina and Clinacanthus nutans. J Ethnopharmacol. 1999;67(2):179-87. 8741(99)00008-2

https://doi.org/10.1016/s0378

39. Gupta RS, Kumar P, Dixit VP, Dobhal MP. Antifertility studies of the root extract of the Barleria prionitis Linn. in male albino rats with special reference to testicular cell population $\begin{array}{lll}\text { dynamics. J Ethnopharmacol. 2000;70(2):111-77. } & \end{array}$ https://doi.org/10.1016/s0378-8741(99)00150-6

40. Unny R, Chauhan AK, Joshi YC, Dobhal MP, Gupta RS. A review on potentiality of medicinal plants as the source of new contraceptive principles. Phytomedicine. 2003;10(23):233-60. https://doi.org/10.1078/094471103321659997

41. Wanichacheewa S, Singtripop T, Sassa S, Sakamoto S, Mori T. Decrease in the number of sperm associated with decreased blood testosterone levels in male rats treated with extracts from seven plants consumed by natives of northern Thailand. Environ Toxicol Pharmacol. 2001;10(1-2):1-4. https://doi.org/10.1016/s1382-6689(00)00071-5

42. Verma PK, Sharma A, Joshi SC, Gupta RS, Dixit VP. Effect of isolated fractions of Barleria prionitis root methanolic extract on reproductive function of male rats: Preliminary study. Fitoterapia. https://doi.org/10.1016/j.fitote.2005.03.007

43. Lans C, Harper T, Georges K, Bridgewater E. Medicinal and ethnoveterinary remedies of hunters in Trinidad. BMC Complement Altern Med. 2001;1:10. https://doi.org/10.1186/1472-6882-1-10

44. Suba Y, Murugesan T, Kumaravelrajan R, Mandal SC, Saha BP. Antiinflammatory, analgesic and antiperoxidative efficacy of Barleria lupulina Lindl. extract. Phyther Res. 2005;19(8):695-95. https://doi.org/10.1002/ptr.1734

45. Wanikiat P, Panthong A, Sujayanon P, Yoosook C, Rossi AG, Reutrakul V. The anti-inflammatory effects and the inhibition of neutrophil responsiveness by Barleria lupulina and Clinacanthus nutans extracts. J Ethnopharmacol. 2008;116(2):234-44. https://doi.org/10.1016/j.jep.2007.11.035

46. Singh B, Bani S, Gupta DK, Chandan BK, Kaul A. Antiinflammatory activity of "TAF" an active fraction from the plant Barleria prionitis Linn. J Ethnopharmacol. 2003;85(23):187-93. https://doi.org/10.1016/s0378-8741(02)00358-6

47. Maji AK, Bhadra S, Mahapatra S, Banerji P, Banerjee D. Mast cell stabilization and membrane protection activity of Barleria prionitis L. Pharmacogn J. [Internet]. 2011;3(24):6771. https://doi.org/10.5530/pj.2011.24.13

48. Singh K, Kaur R, Singh S, Bajwa BS, Prasad DN. Antiinflammatory activity of Barleria prionitis Linn. J Nat Remedies. 2013;13(1):1-3.

49. Ghule B V., Kotagale NR, Patil KS. Inhibition of the proinflammatory mediators in rat neutrophils by shanzhiside methyl ester and its acetyl derivative isolated from Barleria prionitis. J Ethnopharmacol. [Internet]. 2020;249:112374. https://doi.org/10.1016/j.jep.2019.112374

50. Juvekar A, Gambhire M, Wankhede S. Antiinflammatory activity of aqueous extract of Barleria cristata leaves. J Young Pharm. 2009;1(3):220-24. https://doi.org/10.4103/09751483.57068

51. Mazumder PM, Sasmal D, Choudhary RK. Wound healing potential of the leaf extracts of Barleria cuspidata Heyne ex Nees. Pharmacologyonline. 2009;1:357-62.

52. Sridharan S, Meenaa V, Kavitha J, Brindha P, Sasikumar C 
Barleria montana wight and nees - a promising natural antiinflammatory agent against formalin induced inflammation. Int J Pharm Pharm Sci. 2015;7(9):80-84.

53. Suba V, Murugesan T, Rao RB, Pal M, Mandal SC, Saha BP Neuropharmacological profile of Barleria lupulina Lindl. extract in animal models. J Ethnopharmacol. 2002;81(2):25155. https://doi.org/10.1016/s0378-8741(02)00087-9

54. Amoo SO, Ndhlala AR, Finnie JF, Van Staden J. Antifungal, acetylcholinesterase inhibition, antioxidant and phytochemical properties of three Barleria species. South African J Bot. [Internet]. 2011;77(2):435-45. https://doi.org/10.1016/j.sajb.2010.11.002

55. Atif M, Rahman SA, Ahmed MI, Mahmood SB, Azharuddin M. Anticataract potential of Barleria prionitis: In vivo study. Int J Pharm Pharm Sci. 2015;7(2):100-55.

56. Sawarkar HA, Kashyap PP, Kaur CD. RBC haemolysis prevention and antioxidant activity of Barleria prionitis. Chiang Mai J Sci. 2018;45(2):888-96.

57. Yadav SA, Raj AJ, Sathishkumar R. In vitro antioxidant activity of Barleria noctiflora L. f. Asian Pac J Trop Biomed. [Internet]. 2012;2(2 SUPPL.):S716-22. https://doi.org/10.1016/S2221-1691(12)60302-5

58. Narmada $\mathrm{R}$, Devaki $\mathrm{K}$. In vitro antioxidant activity and invitro a-glucosidase and a -amylase inhibitory activity of Barleria cristata L. Res J Pharm Biol Chem Sci. 2012;3(4):78088.

59. Tamboli F, More H. Evaluation of antiulcer and antioxidant activity of Barleria gibsonii Dalz. leaves. Pharmacognosy Res. 2016;8(4):226-30. https://doi.org/10.4103/0974-8490.188879

60. Mazumder PM, Mondal A, Sasmal D, Arulmozhi S, Rathinavelusamy P. Evaluation of antiarthritic and immunomodulatory activity of Barleria lupulina. Asian Pac J Trop Biomed. [Internet]. 2012;2(3 SUPPL.):S1400-6. https://doi.org/10.1016/S2221-1691(12)60425-0

61. Ghule B V., Yeole PG. In vitro and in vivo immunomodulatory activities of iridoids fraction from Barleria prionitis Linn. J $\begin{array}{ll}\text { Ethnopharmacol. [Internet]. 2012;141(1):424-31. } & \text {. }\end{array}$ https://doi.org/10.1016/j.jep.2012.03.005

62. Johnson Inbaraj J, Krishna MC, Gandhidasan R, Murugesan R. Cytotoxicity, redox cycling and photodynamic action of two naturally occurring quinones. Biochim Biophys Acta - Gen Subj. 1999;1472(3):462-70. https://doi.org/10.1016/s03044165(99)00150-6

63. Manglani N, Vaishnava S, Dhamodaran P, Sawarkar H. In vitro and in vivo anti-cancer activity of leaf extract of Barleria grandiflora. Int J Pharm Pharm Sci. 2014;6(3):70-72.

64. Choudhary M, Kumar V, Gupta PK, Singh S. Anti-arthritic activity of Barleria prionitis Linn. leaves in acute and chronic models in Sprague Dawley rats. Bull Fac Pharmacy, Cairo $\begin{array}{ll}\text { Univ. } & \text { [Internet]. }\end{array}$ https://doi.org/10.1016/j.bfopcu.2014.07.002

65. Suba V, Muragesan T, Pal M, Mandal SC, Saha BP. Antiulcer activity of methanol fraction of Barleria lupulina Lindl. in animal models. Phyther Res. 2004;18(11):925-29. https://doi.org/10.1002/ptr.1587

66. Jaiswal SK, Dubey MK, Das S, Rao C V. Gastroprotective effect of the iridoid fraction from Barleria prionitis leaves on experimentally-induced gastric ulceration. Chin J Nat Med. [Internet]. 2014;12(10):738-44. https://doi.org/10.1016/S18755364(14)60113-8

67. Suba V, Murugesan T, Arunachalam G, Mandal SC, Saha BP Anti-diabetic potential of Barleria lupulina extract in rats. Phytomedicine.

https://doi.org/10.1016/s0367-326x(03)00163-1

2004

68. Dheer R, Bhatnagar P. A study of the antidiabetic activity of Barleria prionitis Linn. Indian J Pharmacol. 2010;42(2):70-73. https://doi.org/10.4103/0253-7613.64493

69. Arumugam S, Natesan S. Hypoglycemic effects of Barleria noctiflora fractions on high fat fed with low dose Streptozotocin induced type-2 diabetes in rats. Int J Pharm Pharm Sci. 2016;8(2):193-200.

70. Vasanth S, Bupesh G, Vijayakumar TS, Balachandar V,
Gunasekaran DR. Evaluation of in vitro antidiabetic and antioxidant potential of Barleria cristata leaves extracts. Asian J Pharm Clin Res. 2018;11(4):287-90. https://doi.org/10.22159/ajpcr.2018.v11i4.24069

71. Singh B, Chandan BK, Prabhakar A, Taneja SC, Singh J, Qazi GN. Chemistry and hepatoprotective activity of an active fraction from Barleria prionitis Linn. in experimental animals. Phyther Res. 2005;19(5):391-404. https://doi.org/10.1002/ptr.1509

72. Banu S, Arunachalam G, Jayaveera KN, Babu VA, Kumar V. Hepatoprotective activity of methanolic extract of Barleria montana leaves in ethanol treated rats. Asian Pacific J Trop Dis. [Internet]. 2012;2(SUPPL2):S748-52. https://doi.org/10.1016/S2222-1808(12)60257-6

73. Tulliballi S, Seru G. Phytochemical investigation and evaluation of hepatoprotective and antimicrobial activities on the aerial parts of Barleria montana (Acanthaceae). Rasayan J Chem. 2013;6(2):102-16.

74. Amit K, Shiwani S, Rajesh K, Rajinder K, Singh LK, Shilpa K. Pharmacognostical, preliminary phytochemical screening and antimicrobial studies of leaves of Barleria prionitis Linn. Int J Pharmacogn Phytochem Res. 2014;6(2):369-78.

75. Yuliastuti F, Hapsari WS, Syarifuddin A, Septianingrum NMAN, Pradani MPK. Fractionation antibiotic isolate: Trial protocol for antibiotic compound from Barleria prionitis L. extract. Technol Reports Kansai Univ. 2020;62(3):989-94.

76. Natarajan D, Gomathi M, Yuvarajan R. Phytochemical and antibacterial evaluation of Barleria montana Nees. Academic Sciences. Asian J Pharm Clin Res. 2011;5(3):44-46.

77. Kumari S, Jain P, Sharma $\mathrm{B}$, Kadyan $\mathrm{P}$, Dabur $\mathrm{R}$. In vitro antifungal activity and probable fungicidal mechanism of aqueous extract of Barleria grandiflora. Appl Biochem Biotechnol. https://doi.org/10.1007/s12010-015-1527-0

78. Pal A, Kumar R, Upadhyay L, Tripathi YC. Antifungal activity of natural dye from aerial biomass of Barleria prionitis $\mathrm{L}$. and dyed fabrics. Iran J Chem Chem Eng. 2018;37(1):213-21. https://doi.org/10.30492/IJCCE.2018.30706

79. Jaiswal SK, Dubey MK, Verma AK, Das S, Vijaykumar M, Rao C V. Evaluation of iridoid glycosides from leaves of Barleria prionitis as an anti-diarrhoeal activity: An ethnopharmacological study. Int J Pharm Sci. 2010;2(3):68086.

80. Marya BH, Bothara SB. Investigation of antihypertensive activity of leaves of Barleria prionotis in doca salt induced hypersensitive rats. Int J Pharma Sci Res. 2013;18(2):17-19.

81. Wang C, Gong X, Bo A, Zhang L, Zhang M, Zang E et al Iridoids: Research advances in their phytochemistry, biological activities, and pharmacokinetics. Molecules. 2020;25(2):287. https://doi,org/10.3390/molecules25020287

82. Devi N, Parashar B, Thakur R. Comparative, evaluation parameter for toothpaste : A Review. 2019;03(06):57-64.

83. Kotteswari M, Krishna Rao MR, Prabhu K, Kumar S, Shil S. Antioxidant studies of one ayurvedic medicine Aswagandharishtam. Asian J Pharm Clin Res. 2018;11(11):227-31. https://doi.org/10.22159/ajpcr.2018.v11i11.27593

84. Vador N, Vador B, Rajgor N. Anti-oxidant and anti-arthritic potential of ayurvedic formulations: Maharasnadi quath extract and Stifain tablet. Indian J Pharm Pharmacol. 2020;7(1):43-47. http://doi.org/10.18231/j.ijpp.2020.009

85. Lone SA, Yadav AS, Badkhane Y, Sharma AK, Bakhshi SH, Raghuwanshi DK. Effect of different plant growth regulators on in-vitro propagation of Barleria prionitis L.- a threatened medicinal plant. Int J Pharma Bio Sci. 2011;2(1):438-44.

86. Lone SA, Yadav AS, Bajaj A, Sharma AK, Badkhane Y, Raghuwanshi DK. Conservation strategies for threatened medicinal plant - Barleria prionitis L. using in vitro and ex vitro propagation techniques. Arch Phytopathol Plant Prot. 2012;45(11):1327-40. https://doi.org/10.1080/03235408.2012.673301

87. Singh R, Arya S, Arora K, Chodhurary M, Dev I. Micropropagation of Barleria prionitis L. var. dicantha: an 
ethnomedicinal plant. Adv For Sci. 2015;2(24):73-78. https://doi.org/10.34062/afs.v2i4.2651

88. Kumar S, Rani A. Micropropagation of vajradanti (Barleria prionitis L.): a high value antidontalgic and ethno-medicinal herb. J Phytol Res. 2016;29:1-6.

89. Soni V, Kumari R, Swarnkar PL. High frequency in vitro regeneration system for conservation of Barleria prionitis L., a threatened medicinal shrub. Bot Pacifica. 2017;6(1):45-49. https://doi.org/ 10.17581/bp.2017.06104

90. Shukla P, Singh A, Gawri S AA. and SS. In vitro propagation of Barleria prionitis Linn. and its antibacterial activity. Int J Pharma Prof Res. 2011;2:198-200.

91. Moin S, Babu SS, Mahalakshmipriya A. In vitro callus production and antibacterial activity of Barleria lupulina Lindl. Asia-Pacific J Mol Biol Biotechnol. 2012;20(2):59-64.

92. Kumari P, Yadav P, Arya A, Kumar S. In vitro callus production and anti-bacterial activity of Barleria prionitis Linn. against dental caries pathogens. Int $\mathrm{J}$ Bot Res. 2013;3(4):1-6.

93. Kumar S. Establishment of callus cultures and their PhysicoBiochemical analysis in Barleria lupulina Lindl. Intern Res
Jour Managt Socio Human. 2018;9(11):244-51. https://doi.org 10.32804/IRJMSH

\section{Additional information}

Peer review information: Plant Science Today thanks Sectional Editor and the other anonymous reviewers for their contribution to the peer review of this work.

Reprints and permissions information is available at https://horizonepublishing.com/journals/index.php/PST/open_access_policy

Publisher's Note: Horizon e-Publishing Group remains neutral with regard to jurisdictional claims in published maps and institutional affiliations.

To cite this article: Sudheer W N, Praveen N. Phytochemical, pharmacological and tissue culture studies of some important species of genus Barleria L. (Acanthaceae) - a review. Plant Science Today. 2021;8(3):491-500. https://doi.org/10.14719/pst.2021.8.3.1117

Plant Science Today, published by Horizon e-Publishing Group, is covered by Scopus, Web of Science, BIOSIS Previews, Clarivate Analytics, etc. See https://horizonepublishing.com/journals/index.php/PST/indexing_abstracting 